\title{
The phosphatidylinositol 3-kinase/Akt/mTOR signaling network as a therapeutic target in acute myelogenous leukemia patients
}

\author{
Alberto M. Martelli, ${ }^{1,2}$, Camilla Evangelisti ${ }^{1}$, Francesca Chiarini' ${ }^{1}$ James A. \\ McCubrey ${ }^{3}$ \\ 1 Department of Human Anatomical Sciences University of Bologna, Bologna, Italy \\ 2 IGM-CNR, Sezione di Bologna c/O I.O.R., Bologna, Italy \\ 3 Department of Microbiology \& Immunology, School of Medicine, East Carolina University, Greenville, NC 27834, USA \\ Correspondence to: Dr. Alberto M. Martelli, Dipartimento di Scienze Anatomiche Umane \\ Università di Bologna, 40126 Bologna, Italy \\ Tel: +39-05 1-2091580, Fax: +39-05 1-2091695, e-mail: alberto.martelli@gmail.com
}

Running title: Targeting PI3K/AKt/mTOR in AML

Key words: PI3K/AKt/mTOR, leukemia, leukemic stem cells, signal transduction modulators, targeted therapy, combination therapy

Received: December 3, 2009, Accepted: May 2, 2010, Published: on line May 27, 2010

Copyright: C 2010 Martelli et al. This is an open-access article distributed under the terms of the Creative Commons Attribution License, which permits unrestricted use, distribution, and reproduction in any medium, provided the original author and source are credited.

\section{ABSTRACT:}

The phosphatidylinositol 3-kinase (PI3K)/Akt/mammalian target of rapamycin (mTOR) signaling axis plays a central role in cell proliferation, growth, and survival under physiological conditions. However, aberrant PI3K/Akt/mTOR signaling has been implicated in many human cancers, including acute myelogenous leukemia (AML). Therefore, the PI3K/Akt/mTOR network is considered as a validated target for innovative cancer therapy. The limit of acceptable toxicity for standard polychemotherapy has been reached in AML. Novel therapeutic strategies are therefore needed. This review highlights how the PI3K/Akt/mTOR signaling axis is constitutively active in AML patients, where it affects survival, proliferation, and drug-resistance of leukemic cells including leukemic stem cells. Effective targeting of this pathway with small molecule kinase inhibitors, employed alone or in combination with other drugs, could result in the suppression of leukemic cell growth. Furthermore, targeting the PI3K/Akt/mTOR signaling network with small pharmacological inhibitors, employed either alone or in combinations with other drugs, may result in less toxic and more efficacious treatment of AML patients. Efforts to exploit pharmacological inhibitors of the PI3K/Akt/mTOR cascade which show efficacy and safety in the clinical setting are now underway.

\section{INTRODUCTION}

Acute myelogenous leukemia (AML) is a highly heterogeneous group of malignant clonal diseases characterized by deregulated proliferation of hematopoietic stem cells and myeloid progenitors. This results in accumulation, in the bone marrow, of myeloid cells with an impaired differentiation program and resistant to cell death. AML accounts for about $80 \%$ of adult leukemias and is a disorder of the elderly, with a median age at diagnosis of 65 years and a growing incidence over 65 years [1]. Most AML cases respond well to initial polychemotherapy, but disease relapse occurs in the large majority of patients. The standard therapeutic approach for AML patients is high- dose polychemotherapy, consisting of cytarabine and an anthracycline antibiotic like daunorubicin or idarubicin, or the anthracendione mitoxantrone [2]. While results of AML treatment have improved in younger patients who can tolerate intensified treatment strategies, there have been limited changes in outcome among individuals who are older than 60 years. Therefore, the prognosis of AML remains severe, with an overall 5-year survival rate around $20 \%$, despite continuous advances in our understanding of AML biology. Furthermore, patients with AML arising out of myelodysplastic syndrome or who are older than 60 years have an even worse prognosis $(<10 \%$ survival at 5 years) [3]. Therefore, there remains a need for innovative, rationally designed, minimally toxic, therapies for AML, 
especially for the elderly [4].

Only one subtype of AML, acute promyelocytic leukemia (APL), displays a much better prognosis, as differentiation therapy with arsenic trioxide or all-trans retinoic acid (ATRA), used alone or in combination with chemotherapeutic drugs, has proven quite successful in APL patients [5]. It is now clear that a hierarchical organization of the hematopoietic system does exist in AML, as in normal hematopoiesis. Indeed, AML is initiated and maintained by a small, self-renewing population of leukemic stem cells (LSCs), which give rise to a progeny of more mature and highly cycling progenitors (colony forming unit-leukemia, CFU-L). CFU-Ls do not self-renew, however they are committed to proliferation and limited differentiation. By doing so, they originate a population of blast cells which constitute the majority of leukemic cells in both the bone marrow and peripheral blood of patients. The exact phenotype of
LSCs is still debated, but they are comprised in the $\mathrm{CD} 34^{+} /$ CD38-1/ow population [6]. The majority of LSCs are quiescent and insensitive to traditional chemotherapeutic drugs. This latter feature explains, at least in part, the difficulties in eradicating this cell population by conventional polychemotherapy. Thus, novel therapeutic strategies for AML eradication should also target LSCs [7]. In AML, aberrant activation of several signal transduction pathways strongly enhances the proliferation and survival of both LSCs and CFU-Ls $[8,9]$. Therefore, these signaling networks are attractive targets for the development of innovative therapeutic strategies in AML [10].

The phosphatidylinositol 3-kinase (PI3K, a family of lipid kinases)/Akt/mammalian target of rapamycin (mTOR) signaling cascade is crucial to many widely divergent physiological processes which include cell cycle progression, transcription, translation, differentiation, apoptosis,

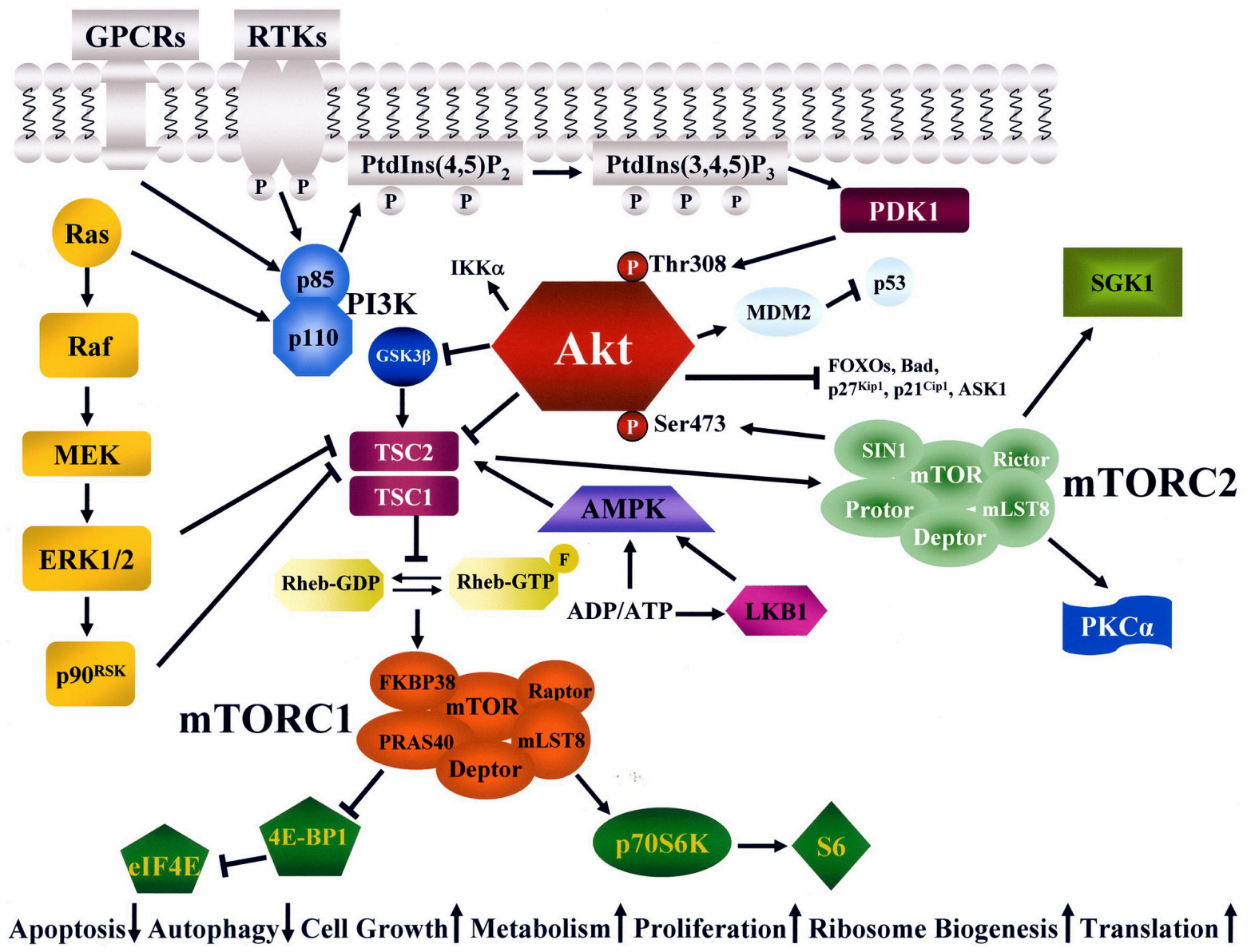

Fig. 1. The PI3K/Akt/mTOR signaling pathway. GPCRs, RTKs, and Ras activate PI3K. PI3K generates $P$ tdlns $(3,4,5) P_{3}$ from $P$ tdlns $(4,5)$ $P_{2}$. Ptdlns $(3,4,5) P_{3}$ attracts to the plasma membrane PDK1 which phosphorylates Akt on Thr308. Full Akt activation requires Ser473 phosphorylation which is effected by mTORC2. Most of the Akt substrates are inactivated by phosphorylation. Active Akt inhibits TSC2 activity through direct phosphorylation. TSC2 is a GAP that functions in association with TSC1 to inactivate the small G protein Rheb. Akt-driven TSC1/TSC2 complex inactivation allows Rheb to accumulate in a GTP-bound state. Rheb-GTP then activates the protein kinase activity of mTORC1. mTORC1 targets p70S6K and 4E-BP1 which are critical for translation. 4E-BP1 phosphorylation by mTORC1 results in the release of elF4E, while p70S6K phosphorylates ribosomal S6 protein. The TSC1/2 complex is required to activate also $\mathrm{mTORC2}$. However, other signaling cascades impinge on mTORC1, including GSK3 $\beta$, the Ras/Raf/MEK/ERK1/2/p90RSK pathway, and the LKB1/AMPK network which is sensitive to the ADP/ATP ratio. Arrows indicate activating events, whereas perpendicular lines indicate inhibitory events. 
motility, and metabolism [11]. However, the PI3K/Akt/ mTOR signaling pathway represents one of the major survival pathways that is deregulated in many human cancers and contributes to both cancer pathogenesis and therapy resistance. Over the last few years, it has been reported that constitutive activation of the PI3K/Akt/mTOR signaling network is a common feature of AML patients [12]. Furthermore, pathway activation confers leukemogenic potential to mouse hematopoietic cells [13]. Therefore, this signal transduction cascade may represent a valuable target for innovative therapeutic treatment of AML patients. The aim of this review is to give the reader an updated overview of the relevance of PI3K/Akt/mTOR signaling activation in AML patients and to focus on small molecules which will possibly have an impact on the therapeutic arsenal we have against this disease.

\section{The PI3K/Akt/mTOR pathway}

\section{PI3K}

The family of PI3K enzymes is characterized by the ability to phosphorylate the 3'-OH group in inositol lipids and comprises three different classes, I, II, and III. Class I PI3K preferred substrate is phosphatidylinositol 4,5 bisphosphate [PtdIns $(4,5) \mathrm{P}_{2}$ ] which is phosphorylated to phosphatidylinositol 3,4,5 trisphosphate [PtdIns $(3,4,5) \mathrm{P}_{3}$ ] $[14,15]$. PtdIns $(3,4,5) \mathrm{P}_{3}$ recruits to the plasma membrane pleckstrin homology $(\mathrm{PH})$ domain-containing proteins, which include phosphoinositide-dependent protein kinase 1 (PDK1) and Akt. Class I PI3K is divided further into A [activated by receptor tyrosine kinases (RTKs), Ras, and G-protein coupled receptors (GPCRs)] and B (activated by GPCRs) subtype (Figure 1). Class IA PI3Ks are heterodimeric enzymes composed of a regulatory (p85a, p85 $\beta$, $\mathrm{p} 55 \alpha, \mathrm{p} 55 \gamma, \mathrm{p} 50 \alpha)$ and of catalytic (p110 $\alpha, \mathrm{p} 110 \beta, \mathrm{p} 110 \delta)$ subunits. Class IB PI3K comprises a p101 regulatory and a p110 $\gamma$ catalytic subunit [16]. Both p110 $\alpha$ and p110 $\beta$ PI3K play fundamental roles during development, so that their homozygous knockout is embryonic-lethal [17]. In contrast, $\mathrm{p} 110 \gamma$ and $\mathrm{p} 110 \delta$ PI3Ks are mostly related to the immune system functions, so that their knock-down leads to defective immune responses [18]. Class II PI3Ks, which comprise the PI3K-C $2 \alpha,-\mathrm{C} 2 \beta$, and -C $2 \gamma$ isoforms, preferentially phosphorylate phosphatidylinositol to yield phosphatidylinositol 3 phosphate. Although class II PI3Ks are widely expressed in mammalian organs and tissues, their relevance in cell signaling and cancer biology is not clear at the moment [19].

Vacuolar protein sorting 34 (vps34) is the only class III PI3K and exists as a heterodimer bound to the vps 15 regulatory subunit (previously referred to as p150 in mammals). Vps34 has been implicated in nutrient signaling, endocytosis, and autophagy [20].

Activating mutations in the gene coding for $\mathrm{p} 110 \alpha$ (PIK3CA) have been found in many human cancer types, including tumors of the colon, brain, ovary, breast, liver, and stomach, and could at least partially explain pathway up-regulation in these neoplasms [21]. Nevertheless, in tumor models (brain, prostate, breast) driven by PTEN (phosphatase and tensin homolog deleted on chromosome 10) deficiency, knock-out of $\mathrm{p} 110 \beta$, but not $\mathrm{p} 110 \alpha$, was required to inhibit Akt activation [17]. Wild-type p110 $\alpha$ is not oncogenetic when overexpressed, whereas wild-type $\mathrm{p} 110 \beta, \mathrm{p} 110 \gamma$, and $\mathrm{p} 110 \delta$ PI3Ks are oncogenetic when ectopically expressed in chicken fibroblasts [22]. Nevertheless, their contribution to oncogenesis is only beginning to emerge [23].

\section{Akt}

Akt, a 57-kDa serine/threonine protein kinase, is the cellular homolog of the v-akt oncogene. The Akt family comprises three highly conserved isoforms: Akt $1 / \alpha, \mathrm{Akt} 2 / \beta$, and Akt $3 / \gamma$, which display a high degree of sequence homology [14]. However, functional differences exist between Akt isoforms, as Akt2 is involved in insulin-mediated glucose uptake [24] and in cell motility/invasion/metastatic potential of cancer cells [25].

Akt contains an $\mathrm{NH}_{2}$-terminal $\mathrm{PH}$ domain, that interacts with PtdIns $(3,4,5) \mathrm{P}_{3}$. Once Akt is recruited at the plasma membrane, its activation loop is phosphorylated on Thr308 by PDK1 while the mTOR complex 2 (mTORC2) phosphorylates Ser473 in the Akt COOH-terminus (Figure 1). Full Akt activation requires both the phosphorylation steps. Active Akt migrates to both the cytosol and the nucleus. Nuclear Akt may fulfil important anti-apoptotic roles [26]. Nevertheless, the relative contribution of Akt signaling at the plasma membrane, the cytosol, and the nucleus remains to be elucidated. However, it is intriguing that the protein promyelocytic leukemia (PML) is involved in the dephosphorylation of nuclear Akt as PML specifically recruits the Akt phosphatase, protein phosphatase 2A (PP2A), as well as phosphorylated Akt into PML nuclear bodies [27]. These bodies, however, are disrupted by the fusion protein, PMLRAR $\alpha$, which is the hallmark of APL [5, 28]. This could be one of the reasons for Akt activation which is detected in APL [29]. Thus, this finding highlights the growing importance of Akt compartmentalization in human cancer pathogenesis and treatment.

So far, over 100 Akt substrates have been identified [30]. Of these, about 40 which mediate the pleiotropic Akt functions have been characterized, including Bad, caspase-9, murine double minute 2 (MDM2), IкB kinase (IKK) $\alpha$, proline-rich Akt substrate 40-kDa (PRAS40) 40, the FOXO family of Forkhead transcription factors, apoptosis signal-regulated kinase 1 [ASK1, a negative regulator of pro-apoptotic c-Jun N-terminal kinase (JNK)], Raf,

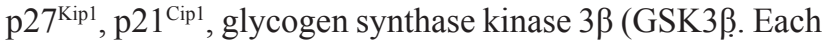
of these substrates has a key role in the regulation of cell survival and proliferation, either directly or through an intermediary [16, 31]. A rare, oncogenetic, activating muta- 
tion $(\mathrm{E} 17 \mathrm{~K})$ in the $\mathrm{PH}$ domain of Akt1 has been detected in some types of solid cancers (breast, colon, ovary). This mutation resulted in Akt constitutive binding to the plasma membrane and was leukemogenic in mice [32].

\section{mTOR}

mTOR is an atypical $289-\mathrm{kDa}$ serine/threonine kinase, originally identified in the yeast Saccharomyces Cerevisiae, that belongs to the PI3K-related kinase family and displays a $\mathrm{COOH}$-terminal catalytic domain with a high sequence homology to PI3K (Figure 2). This similarity could explain the cross-inhibition of mTOR by drugs which target PI3K (see below) [33]. mTOR signaling is conserved in eukaryotes from plants and yeasts to mammals. mTOR exists as two complexes, referred to as mTOR complex 1 (mTORC1) and mTORC2. mTORC1 is comprised of mTOR/Raptor/mLST8/PRAS40/FKBP38/Deptor and is sensitive to rapamycin and its derivatives (rapalogs). mTORC2 is composed of mTOR/Rictor/mLST8/SIN1/ Protor/Deptor and is generally described as being insensitive to rapamycin/rapalogs, although long-term treatment of about $20 \%$ of cancer cell lines with rapamycin/rapalogs leads to dissociation of mTORC2 [34, 35]. mTORC1 signaling integrates environmental clues (growth factors, hormones, nutrients, stressors) and information from the cell metabolic status. Thus, mTORC1 controls anabolic processes for promoting protein synthesis and cell growth [36]. mTORC1 regulates translation in response to nutrients/growth factors by phosphorylating components of the protein synthesis machinery, including p70S6 kinase (p70S6K) and eukaryotic initiation factor 4E-binding protein 1 (4E-BP1). p70S6K phosphorylates the 40S ribosomal protein, S6, leading to active translation of mRNAs, while 4E-BP1 phosphorylation by mTORC1 on several amino acidic residues (Ser37; Thr46; Ser65; Thr70) results in the release of the eukaryotic initiation factor 4E (eIF4E). eIF4E is a key component for translation of 5' capped mRNAs, which include transcripts encoding growth promoting molecules, such as c-Myc, cyclin D1, cyclin-dependent kinase 2 , retinoblastoma protein, p27Kip1, vascular endothelial growth factor (VEGF), and signal activator and transducer of transcription 3 (STAT3) $[34,37]$. Furthermore, mTORC1 negatively regulates autophagy, a non-apoptotic form of cell death, which is attracting much attention, as it could affect sensitivity of tumors (including leukemias) to various forms of therapy [38].

Akt-mediated regulation of mTORC1 activity involves several mechanisms. Akt inhibits TSC2 (Tuberous Sclerosis 2 or hamartin) function through direct phosphorylation. TSC2 is a GTPase-activating protein (GAP) which associates with TSC1 (Tuberous Sclerosis 1 or tuberin) for inactivating the small G protein Rheb (Ras homolog enriched in brain). TSC2 phosphorylation by Akt represses GAP activity of the TSC1/TSC2 complex, allowing Rheb to accumulate in a GTP-bound state. The mechanism by which Rheb-GTP activates mTORC1 has not been fully elucidated yet, although Rheb requires to be farnesylated for activating mTORC1 [39]. Thus, it could be inhibited by farnesyl-trasferase inhibitors (FTIs). Akt also phosphorylates PRAS40, an inhibitor of the interactions between mTORC1 and its substrates, and by doing so, prevents PRAS40 ability to suppress mTORC1 signaling [40]. Moreover, PRAS40 is a substrate of mTORC1 itself, and it has been demonstrated that mTORC1-mediated phosphorylation of PRAS40 facilitates the removal of its inhibition on mTORC1 [41].

Moreover, Ras/Raf/mitogen-activated protein kinase kinase (MEK)/extracellular signal-regulated kinase (ERK) $1 / 2$ signaling positively regulates mTORC 1 activity, as both ERK 1/2 and p90 ribosomal S6 kinase (p90 ${ }^{\mathrm{RSK}}$ ) phos-

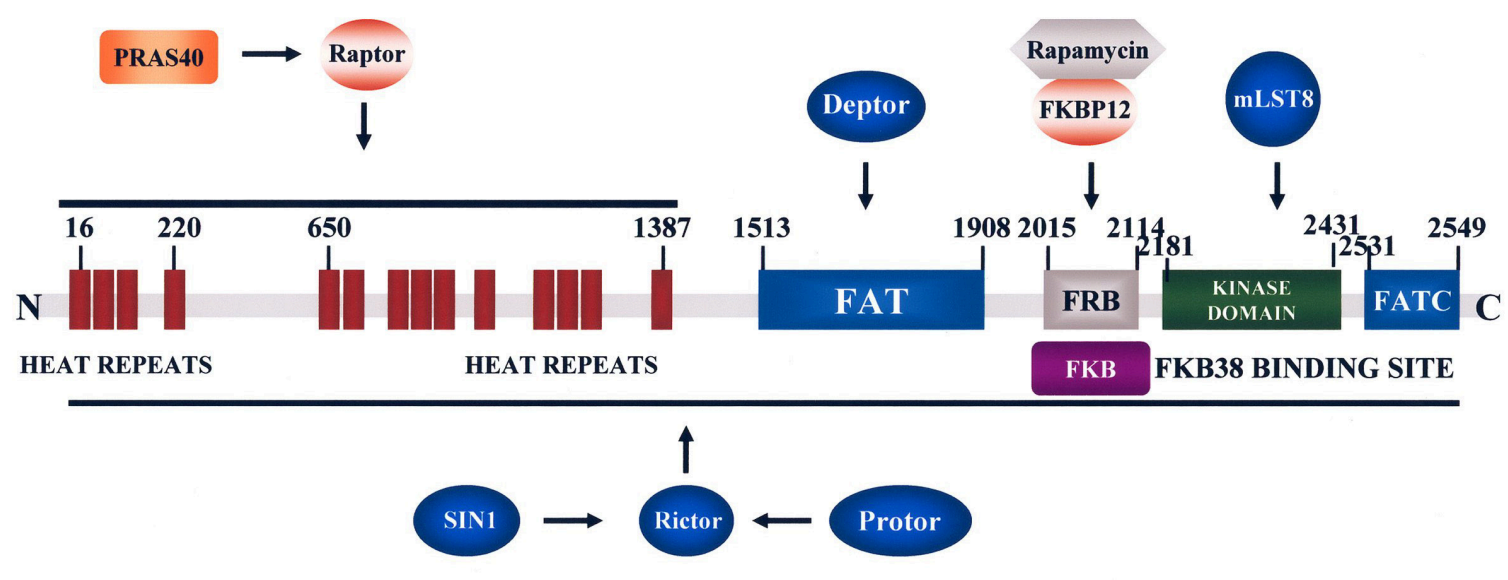

Fig. 2. A schematic presentation of $m T O R$ structure. Some of the proteins interacting with $m T O R$ domains are highlighted. The FRB domain is where the FKBP12 and rapamycin complex binds which is within the region that binds FKBP38. 
phorylate TSC2, thus suppressing its inhibitory function on Rheb [42] (Figure 1). mTORC1 signal transduction is inhibited by the master metabolic regulator, energy-sensing AMP-dependent protein kinase (AMPK), given that AMPK phosphorylates and activates TSC2 [43].

The mechanisms for mTORC2 regulation have only begun to be revealed. However, mTORC2 activation requires PI3K and the TSC1/TSC2 complex, but is independent of Rheb and is largely insensitive to either nutrients or energy conditions [44]. mTORC2 phosphorylates Akt on Ser473 which enhances subsequent Akt phosphorylation on Thr308 by PDK1 [45]. Moreover, mTORC2 plays a role in cytoskeleton organization by controlling actin polymerization [46] and phosphorylates protein kinase $\mathrm{C}$ (PKC) $\alpha$ [44]. Another down-stream target of mTORC2 is serumand glucocorticoid-induced protein kinase 1 (SGK1) [47]. The oncogenetic role of mTORC2 has been recently highlighted by an investigation that documented the importance of mTORC2 in the development and progression of prostate cancers induced in mice by PTEN loss [48].

Akt and mTORC1/2 are linked to each other via positive and negative regulatory feedback circuits, which restrain their simultaneous hyperactivation through mechanisms which involve p70S6K and PI3K. Assuming that an equilibrium exists between mTORC1 and mTORC2, when $\mathrm{mTORC} 1$ is formed, it antagonizes the formation of mTORC2 and reduces Akt activity. Indeed, once mTORC1 is activated through Akt, the former elicits a negative feedback loop for inhibiting Akt activity [34]. This negative regulation of Akt activity by $\mathrm{mTORC} 1$ is a consequence of p70S6K-mediated phosphorylation of insulin receptor substrate (IRS) 1 adapter protein, downstream of insulin receptor and/or Insulin-like Growth Factor-1 Receptor (IGF-1R) [49, 50]. Indeed, IRS-1 phosphorylation on Ser307 and Ser636/639 by p70S6K targets the adapter protein to proteasomal degradation [51]. Therefore, at least in principle, inhibition of mTORC1 activity by rapamycin/rapalogs could result in hyperactivation of both Akt and its downstream targets. Such a phenomenon has been documented to occur both in vitro and in vivo $[52,53]$. mTORC1 is capable of downregulating also IRS2 expression by enhancing its proteosomal degradation [54]. Consistently, mTORC1 inhibition by the rapalog, RAD001, increased IRS2 expression and Akt phosphorylation levels in AML cells [55]. Recent work has also highlighted a p70S6K-mediated phosphorylation of Rictor on Thr1135. This phosphorylation event exerted a negative regulatory effect on the mTORC2-dependent phosphorylation of Akt in vivo [56]. Thus, both mTORC1 and mTORC2 control Akt activation.

Nevertheless, the extent to which disruption of negative feedbacks mechanism actually limits the therapeutic effects of mTOR inhibitors in cancer patients in vivo remains to be determined [57].

\section{Negative regulation of PI3K/Akt/mTOR signaling}

A tight counter-regulation by phosphatases has emerged as a crucial process to control PI3K/Akt/mTOR-dependent signaling. PTEN is a dual specificity lipid/protein phosphatase that preferentially removes the 3 '-phosphate mainly from PtdIns $(3,4,5) \mathrm{P}_{3}$ but is also active on phosphatidylinositol 3,4 bisphosphate [PtdIns $(3,4) \mathrm{P}_{2}$ ], thereby antagonizing network signaling [58, 59]. PTEN silencing or inactivating mutations have been detected in a wide variety of human neoplasias (including prostatic and endometrium carcinomas, glioblastomas, melanoma, and T-cell acute lymphoblastic leukemia [60]) and this results in Akt/mTOR up-regulation. SHIP-1 and SHIP-2 (for Src homology domain-containing inositol phosphatase) are phosphatases capable of removing the 5-phosphate from PtdIns $(3,4,5) \mathrm{P}_{3}$ to yield PtdIns $(3,4) \mathrm{P}_{2}$ [61]. An important role for SHIP-1 in normal hematopoiesis has been recently described [62, 63]. PP2A, which is now considered to be an oncosuppressor, down-regulates Akt activity, through dephosphorylation of Thr308 [64]. Thr308 and Ser473 residues of Akt are also targeted by the two isoforms ( 1 and 2$)$ of $\mathrm{PH}$ domain leucine-rich repeat protein phosphatase (PHLPP) [65].

\section{Activation of PI3K/Akt/mTOR signals in AML}

From $50 \%$ to $80 \%$ of patients with AML display Akt phosphorylated on either Thr308 or Ser473 (or both) [6671]. Both the disease-free survival and the overall survival were significantly shorter in AML cases where pathway up-regulation was documented [70, 72-74]. Poor prognosis of AML patients with elevated PI3K/Akt/mTOR signaling could be also related to the fact that this pathway controls the expression of the membrane ATP-binding cassette (ABC) transporter, multidrug resistance-associated protein 1 , which extrudes chemotherapeutic drugs from leukemic cells and is usually associated with a lower survival rate $[75,76]$.

Nevertheless, a more recent report has highlighted that constitutive activation of PI3K/Akt/mTOR signaling could be a favourable prognostic factor in de novo cases of AML. One hypothesis for the lower relapse rate in patients with enhanced PI3K/Akt/mTOR signaling is that it could drive immature leukemic cells (LSCs and CFU-L) into S phase, thus rendering them more susceptible to polychemotherapy [77].

Causes of PI3K/Akt $/ \mathrm{mTOR}$ signaling up-regulation in AML may be the result of several factors, including activating mutations of Fms-like tyrosine kinase 3 (FLT3) receptor [71] and c-Kit tyrosine kinase receptor [78], N- or K-Ras mutations [79], PI3K p110 $\beta$ and/or $\delta$ overexpression [8082], low levels of PP2A [70], autocrine/paracrine secretion of growth factors such as IGF-1 [82-84] and VEGF [85, 86]. Overexpression of PDK1 has been reported in $45 \%$ of a cohort of $66 \mathrm{AML}$ patients, however it was related to 
PKC hyperphosphorylation, while the relationship (if any) with Thr308 Akt up-regulation was not investigated [87]. Interactions between leukemic cells and bone marrow stromal cells through CXCR4 (a GPCR which is abundantly expressed on leukemic cell surface where it is up-regulated by hypoxic conditions $[88,89]$ ) and its physiological ligand, CXCL12, produced by stromal cells [89, 90], could result in PI3K/Akt/mTOR activation [91]. Furthermore, interactions between $\beta 1$ integrins on AML cells and stromal fibronectin could lead to pathway activation $[92,93]$, possibly through up-regulation of integrin-linked kinase 1 (ILK1) which is involved in Akt phosphorylation on Ser473 in a PI3K-dependent manner in AML cells [94]. The ability of ILK1 to function as a Ser473 Akt kinase could be related to the fact that ILK1 interacted with Rictor and was required for Akt phosphorylation by mTORC2 on Ser473 [95]. Possible causes of pathway activation in AML cells are highlighted in Figure 3.

No activating mutations in $\mathrm{p} 110 \alpha$ PI3K [96] or Akt1 PH domain [70, 97] have been detected so far in AML patients. Although PTEN is deleted in many solid cancers and T-cell acute lymphoblastic leukemia, PTEN deletion is extremely rare in AML $[66,69,70]$. PTEN can be inactivated by post-translational mechanisms, including phos- phorylation at the $\mathrm{COOH}$-terminal regulatory domain. This phosphorylative event stabilizes PTEN molecule but makes it less active towards PtdIns $(3,4,5) \mathrm{P}_{3}$, thus resulting in Akt up-regulation [98]. PTEN phosphorylation has been reported in AML patients where it was significantly associated with high levels of $\mathrm{p}$-Akt and with shorter overall survival [99]. However, subsequent studies could not confirm these findings [70, 74]. A reassessment of the PTEN role in AML could be important, as in mice, hematopoietic stem cells without functional PTEN, began multiplying rapidly, showed diminished self-renewal capacity, and started to move out of the bone marrow, colonizing distant organs, and originating a leukemic-like disease [100, 101]. Of note, these effects were mostly mediated by mTOR, as rapamycin not only depleted LSCs, but also restored normal hematopoietic stem cell function [101].

It is conceivable that several concomitant extrinsic and intrinsic causes converge to activate PI3K/Akt/mTOR signaling in AML patients, even if this fundamental issue has not been thoroughly investigated. Indeed, in the only published study, it was demonstrated that, in a small cohort of patients, overexpression of PI3K p1108 [81] could coexist with activating FLT3 and Ras mutations. It has also been reported that mTORC1 activation was independent of PI3K/

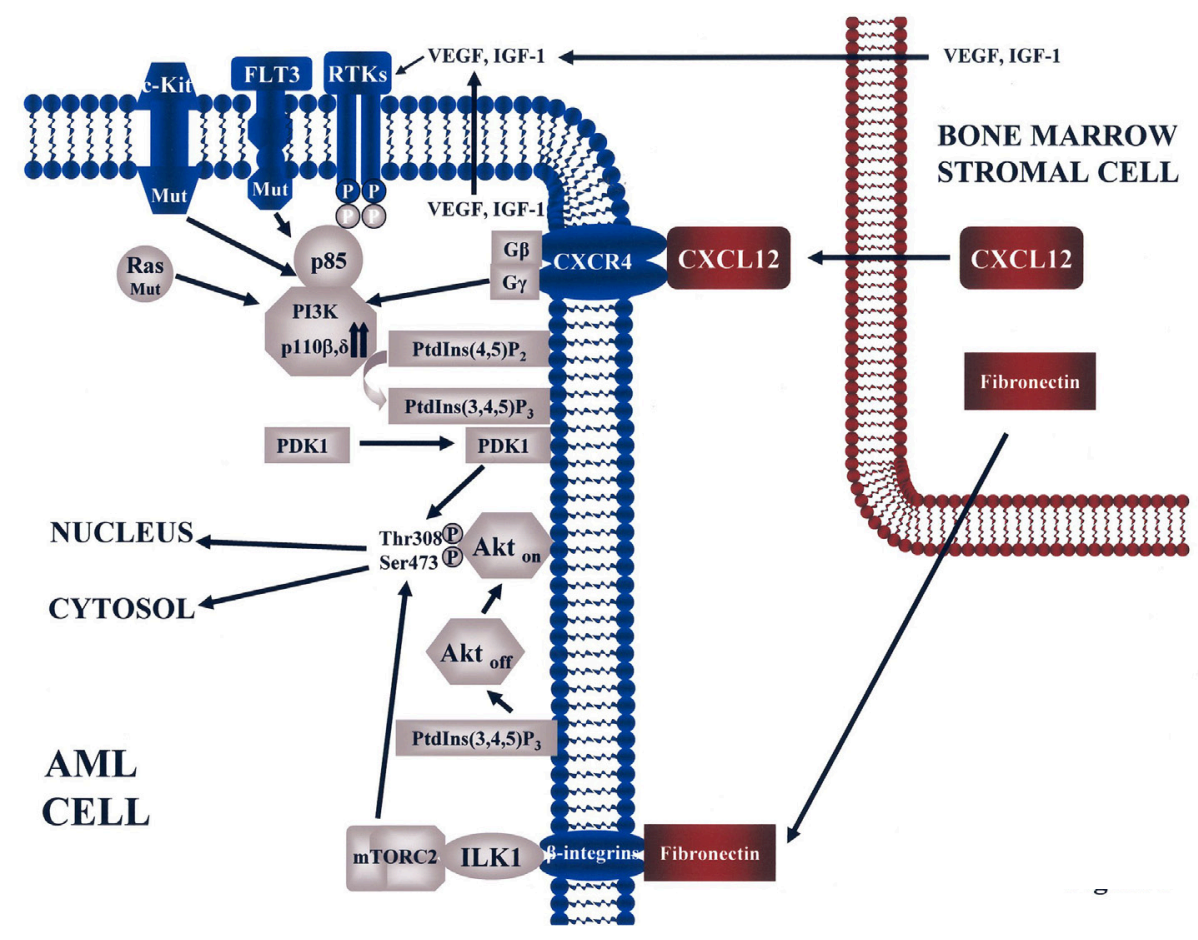

Fig. 3. Constitutive activation of PI3K/Akt signaling in AML cells. In this cartoon, mutated (Mut) C-Kit, FLT3, or Ras, and autocrine/paracrine secretion of growth factors (VEGF, IGF-1) impinge upon increased levels of p110 $\beta$ and/or p1108 PI3K. This results in high levels of Ptdlns $(3,4,5) \mathrm{P}_{3}$ synthesized at the plasma membrane from Ptdlns $(4,5) \mathrm{P}_{2}$. Ptdlns $(3,4,5) \mathrm{P}_{3}$ recruits at the plasma membrane both PDK1 and inactive Akt (Akt off). PDK1 phoshorylates Akt on Thr308, whereas phosphorylation on Ser473 is driven by mTORC2. These two phosphorylative events fully activates Akt (Akt on). Bone marrow stromal cells secrete CXCL12 and fibronectin. Fibronectin, by interacting with $\beta$ integrins, could activate ILK which, in turn, stimulates mTORC2 activity on Ser473 Akt. CXCL12 binds its receptor CXCR4, a GPCR which results in increased PI3K activity. Bone marrow stromal cells could also secrete VEGF and IGF-1. Activated Akt migrates to both nucleus and cytosol to phosphorylate its substrates. 
Akt activity in AML patients [55]. In some AML cases, it has been documented that either MEK/ERK 1/2 [102] or Lyn signaling [103] could be up-stream of mTORC1. TSC2 gene expression was found to be down-regulated in AML patients, most likely due to promoter hypermethylation. However, it is not known if it impinged on mTORC1 activation [104].

It should be emphasized here that PI3K/Akt/mTOR network up-regulation has been detected not only in the bulk of the AML blasts, but also in LSCs transplanted in non-obese diabetic/severe combined immunodeficiency (NOD/SCID) mice, where it exerted a powerful pro-survival effect. This finding suggests that therapeutic targeting of this pathway has the potential for eradicating AML [105].

\section{Targeting PI3K/Akt/mTOR module in AML}

Either used alone or in combination with other drugs, $\mathrm{PI} 3 \mathrm{~K} / \mathrm{Akt} / \mathrm{mTOR}$ signaling inhibitors have been proven useful for down-regulating cell proliferation and inducing apoptosis in pre-clinical settings of AML, using cell lines or animal models. However, clinical trials of these compounds are limited. We shall now highlight some compounds which have been used for targeting PI3K/Akt/ mTOR signaling in AML cells.

\section{PI3K inhibitors}

Wortmannin and LY294002 are the best characterized PI3K inhibitors that have been widely used as research tools to elucidate the role of PI3K/Akt/mTOR signaling in various tumor cells. Both inhibitors are cell-permeable and low molecular weight compounds. Wortmannin is a natural metabolite produced by Penicillium wortmanni and inhibits all class PI3K members with a 50\% inhibitory concentration $\left(\mathrm{IC}_{50}\right)$ in vitro of $2-5 \mathrm{nM}$, while inhibiting other kinases [mTOR, DNA-dependent protein kinase (DNAPK), and ataxia telangiectasia mutated kinase] with higher IC50 values [106]. It is interesting that DNA-PK was found to phosphorylate Akt on Ser473 under conditions of DNA damage [107].

LY294002 is a flavonoid-based synthetic compound and inhibits PI3K with an $\mathrm{IC}_{50}$ of 1-20 $\mu \mathrm{M}$. However, LY294002 blocks not only PI3K activity but also mTOR, DNA-PK, Pim kinase, polo-like kinase, and CK2 to the same extent as PI3K [106]. Both wortmannin and LY294002 bind to the p110 catalytic subunit of PI3K, leading to the blockade of ATP bound to the active portion. PI3K inhibition with LY294002 is reversible and ATP-competitive while wortmannin irreversibly inhibits PI3K in a non-ATP-competitive manner [106].

Wortmannin and LY294002 have been used in preclinical models of AML where they displayed powerful cytotoxic effects in vitro $[66,79,108,109]$. Since the insolubility in aqueous solutions and high toxicity of both inhibitors precluded their clinical application, efforts to develop
PI3K inhibitors more suitable for clinical use are currently underway [110].

Several selective inhibitors of p110 PI3K isoforms are now available [111]. IC87114 is a compound that selectively inhibits the p1108 isoform of PI3K. IC87114 downregulated p-Akt and p-FOXO3a, reduced proliferation, and induced apoptosis in AML primary cells overexpressing p110§PI3K. Moreover, it synergized with etoposide [81]. In primary APL cells, both IC87114 and TGX-115 (a p110 PI3K-selective inhibitor) triggered apoptosis in the presence or in the absence of the differentiating agent, ATRA [29].

Conceivably, the use of selective PI3K isoform inhibitors could be associated with less undesirable side effects than the use of broad spectrum PI3K inhibitors [111]. For example, it is established that insulin control of glucose homeostasis is mainly mediated through p $110 \alpha$ PI3K [112] and, to a much lower extent, by p110 $\beta$ PI3K [113].

\section{Akt inhibitors}

Perifosine is a zwitterionic, water soluble, synthetic alkylphosphocholine with oral bioavailability that inhibits Akt phosphorylation through interaction with the Akt PH domain, resulting in disruption of its membrane targeting. Interestingly, recent evidence has documented that perifosine targets both mTORC1 and mTORC2 activity by downregulating the levels of mTOR, raptor, rictor, p70S6K, and 4E-BP1, owing to their enhanced degradation [114]. Perifosine reduced cell proliferation and induced apoptosis accompanied by Akt dephosphorylation in a wide variety of neoplasias, including AML [115]. Perifosine synergized with etoposide in AML blasts, and reduced the clonogenic activity of $\mathrm{CD} 34^{+}$cells from leukemic patients, but not from healthy donors [116]. Moreover, perifosine synergized with histone deacetylase inhibitors [117] or pro-apoptotic TRAIL (TNF-related Apoptosis Inducing Ligand) in AML cell lines and primary cells displaying Akt constitutive activation [118]. However, perifosine also targeted the MER/ ERK $1 / 2$ pro-survival pathway and activated pro-apoptotic JNK, [116-120] therefore it could not be considered specific for the Akt pathway. A phase 1 clinical trial combining perifosine and UCN-01 (a staurosporine derivative which inhibits PDK1) (NCT00301938) and a phase II clinical trial with perifosine alone (NCT00391560) have been performed in patients with refractory/relapsed AML, but the results have not yet been disclosed.

Akt-I-1/2, a synthetic reversible allosteric inhibitor, is an Akt1/Akt2 isoform-specific inhibitor that forms a $\mathrm{PH}$ domain-dependent inactive conformation with Akt1 and Akt2 [121]. Akt-I-1/2 inhibited cell proliferation and clonogenic properties, and induced apoptosis in AML cells with high-risk cytogenetic changes/abnormalities [70]. However, it is at present unknown which Akt isoforms are expressed by AML blasts. 


\section{mTOR inhibitors}

mTOR inhibitors are by far the most developed class of compounds which target the PI3K/Akt/mTOR pathway. They include: rapamycin (sirolimus, a macrolide derived from the bacterium Streptomyces hygroscopicus, originally discovered in a soil sample collected on Easter Island) and its derivatives CCI-779 (temsirolimus), RAD001 (everolimus), and AP23573 (deforolimus) [122]. Temsirolimus was approved by US Food and Drug Administration in 2007 for the first-line treatment of poor prognosis patients with advanced renal cell carcinoma. The overall survival of treated patients was increased by nearly $50 \%$ ( $\sim 3$ months $)$ relative to the control group [123]. Some clinical benefits of rapamycin/rapalogs have been reported also against endometrial carcinoma and mantle cell lymphoma, however, the overall objective response rates in major solid tumors have been modest [124].

Rapamycin and rapalogs do not target the catalytic site of mTORC1, but rather bind its immunophilin, FK506 binding protein 12 (FKBP12) (Figure 2). The rapamycin/ FKBP12 complex then binds mTORC1 and inhibits downstream signaling events [125]. Thus, rapamycin and rapalogs act as allosteric mTORC1 inhibitors. Recent evidence has documented that complex formation with FKBP12 is not an absolute requirement for repression of $\mathrm{mTORC} 1$ activity by rapamycin/rapalogs, however, in the absence of FKBP12, the drugs display a 100 to 1000 -fold lower potency than in the presence of the immunophilin [126]. Available data suggest that rapamycin treatment, over long time periods, also targets mTORC2 [127]. Accordingly, both CCI-779 and RAD001 (10-20 nM) inhibited Akt phosphorylation on Ser473 in AML cells in vitro and in patients in vivo after a $24 \mathrm{~h}$ incubation, through suppression of the mTORC2 assembly [128]. In contrast, it has been documented that RAD001 (10 nM for $24 \mathrm{~h})$ increased Akt phosphorylation in vitro on Ser473 in AML samples displaying constitutive PI3K/Akt activation [55]. Since a neutralizing monoclonal antibody to the IGF-1R $\alpha$-subunit, reversed the RAD001-induced increase of Akt phosphorylation and RAD001 treatment led to a significant increase in IRS2 protein expression, it was concluded that p-Akt upregulation could be explained by the existence of an IGF-1/ IGF-1R autocrine loop, as well as by increased expression of IRS2. At present, it is not easy to reconcile these contradictory findings.

Rapamycin had only a modest effect on primary AML cell survival in liquid culture, however, it markedly downregulated AML blast clonogenicity while sparing normal hematopoietic precursors [129]. Accordingly, others have reported that rapamycin led to only a slight decrease in AML blast survival in short term cultures, whereas in long term cultures the effect was more pronounced [105]. These results suggested that the target of rapamycin is the proliferating contingent of the leukemic clone, rather than the bulk of AML blasts which are predominantly blocked in the
G0/G1 phase of the cell cycle.

However, rapamycin cytotoxicity in short term cultures could be dramatically increased by co-treatment with etoposide. Importantly, etoposide toxicity on $\mathrm{CD} 34^{+}$cells from healthy donors was not enhanced by addition of rapamycin. Of note, co-incubation with rapamycin enhanced etoposide-mediated decrease in the engraftment of AML cells in NOD/SCID mice, suggesting the drugs also targeted putative LCSs [105].

The rapalog RAD001 synergized with both ATRA and histone acetylase inhibitors in inducing growth arrest and differentiation of APL cell lines [130, 131].

A few phase I/II clinical trials with rapamycin and rapalogs have been performed in patients with relapsed/refractory AML. Rapamycin induced a partial response in 4 of 9 adult patients with de novo or secondary AML, who displayed activation of mTORC1 signaling, as documented by increased levels of p-p70S6K and p-4E-BP1 [129]. RAD001 has been evaluated in a phase I clinical trial in patients with relapsed/refractory hematologic malignancies, including AML [132]. However, no AML patients achieved a complete or even partial response. AP23573 has been tested in a phase II study in 22 patients with AML [133]. Only one patient displayed an objective hematological improvement, consisting of normalization of neutrophils. A significant reduction in $\mathrm{mTORC} 1$ activity was observed in response to the drug, as documented by decreased p-4E-BP1 levels. A recent phase I study in which rapamycin was combined with MEC (mitoxantrone, etoposide, cytarabine) polychemotherapy failed to demonstrate any synergistic effect of the combination in relapsed/refractory AML patients, even if proof of rapamycin biological activity in vivo was detected, consisting in the dephosphorylation of p70S6K [134]. Several clinical trials with rapamycin/rapalogs combined with chemotherapeutic agents are now underway in AML patients [135].

Moreover, a phase I study has recently documented the efficacy, in elderly AML patients, of the combination etoposide and tipifarnib (R11577, an FTI). Intriguingly, the effect of tipifarnib was not always related to Ras inhibition, but rather to inhibition of Rheb farnesylation and, consequently, of mTORC1 signaling, as documented by decreased levels of p-p70S6K and of its substrate, p-S6 [136].

\section{Dual PI3K/mTOR inhibitors}

The rationale for using dual $\mathrm{PI} 3 \mathrm{~K} / \mathrm{mTOR}$ inhibitors is that $\mathrm{mTORC} 1$ allosteric inhibitors, such as rapamycin/rapalogues, could hyperactivate Akt through p70S6K/PI3K, as discussed earlier in this review. Moreover, it is now emerging that rapamycin/rapalogs have only modest efficacy on total translation rates, and the effects are cell-type specific. In contrast, small molecules designed for inhibiting the catalytic site of mTOR, were much more effective in this respect, especially in cancer cells [137-141]. Such 
a phenomenon has been recently reported to occur also in AML cells, where rapamycin was unable to block protein synthesis, owing to a failure in inducing 4E-BP1 dephosphorylation [142]. Furthermore, in some AML cases, mTORC1 activity does not seem to be under the control of PI3K/Akt, despite concomitant PI3K/Akt activation [103]. Therefore, the use of a single inhibitor which targets both PI3K and mTORC1 catalytic sites could present substantial advantages over drugs which only target either PI3K/Akt or mTORC1. PI-103 is a pyridonylfuranopyrimidine class synthetic molecule that represses the activity of both class IA and IB PI3Ks, as well as of mTORC1/mTORC2 [143, 144]. Two papers have documented the efficacy of PI-103 in pre-clinical settings of AML. It has been reported that PI-103, which itself displayed only modest pro-apoptotic activity, acted synergistically with Nutlin-3 (an MDM2 inhibitor) $[145,146]$, to induce apoptosis in a wild-type p53-dependent fashion in AML cell lines and primary cells [147]. Another group demonstrated that PI-103 was mainly cytostatic for AML cell lines. However, in AML blast cells, PI-103 inhibited leukemic proliferation and CFU-L clonogenicity, induced mitochondrial apoptosis, and synergized with etoposide [148]. Of note, PI-103 was not apoptogenic in CD34+ cells from healthy donors and had only moderate effects on their clonogenic and proliferative activities. Since either RAD001 or IC87114 did not induce apoptosis in AML primary cells, it was concluded that dual-targeted therapy against PI3K/Akt and mTOR with PI-103 may be of therapeutic value in AML [148].

Nevertheless, it is conceivable that the new frontier in mTOR inhibition will be represented by the second generation, ATP-competitive mTOR inhibitors which bind the active site of both mTORC1 and mTORC2 [137-140]. These drugs target mTOR signaling functions in a global way, so that they are expected to yield a deeper and broader antitumor response in the clinic. However, global inhibition of mTOR is expected to be accompanied by greater toxicity to normal cells [149].

\section{CONCLUSIONS}

In this review, we have documented that the PI3K/Akt/ mTOR pathway influences proliferation, survival, and drug resistance of AML cells. However, there still are many unresolved problems regarding the relevance of PI3K/Akt/ mTOR pathway up-regulation and its druggability in AML patients. We have a very limited knowledge of the downstream targets (genes/proteins) of this pathway in AML cells. Therefore, more detailed investigations of these targets are highly desirable. Indeed, data emerging from gene expression and proteome/phosphoproteome analysis could pave the way for functional studies which could then provide valuable information for improving future therapeutic strategies. At present, we do not know what is the most effective target in the pathway, and whether combinations of horizontal or vertical blockade of the signaling cascade may be more effective than blocking at a single node [150].

As with all molecularly targeted approaches, pharmacodynamic markers are necessary to direct therapeutic development of PI3K/Akt/mTOR inhibitors. Hence, clinical trials should examine the inhibitor effects on PI3K/Akt/ mTOR targets to establish the best predictor of response [151]. However, no predictive markers for AML patients with a high probability of responding to PI3K/Akt/mTOR inhibition, or biomarkers of dose/efficacy, have been validated. Quantitative flow cytometry appears particularly well suited for this kind of analysis, because it offers obvious advantages over other techniques (western blot, for example), including quickness, a much lower number of cells required to perform the assay, and the possibility of identifying different subclones in the leukemic population by co-immunostaining with multiple antibodies to surface antigens. Accordingly, flow cytometry is rapidly becoming the choice analytical technique to study PI3K/Akt/mTOR pathway activation in AML patients [70, 133, 152, 153]. Another promising quantitative technique requiring a limited number of cells, which has been already applied to the study of AML patients samples, is represented by reversephase protein arrays [74].

It is highly unlikely that inhibition of a single signaling pathway will achieve long-lasting remissions or cure in AML, especially for refractory/relapsed patients. However, combining PI3K/Akt/mTOR inhibitors with conventional chemotherapy drugs, differentiation inducers (ATRA and/or arsenic trioxide), or innovative (e.g. TRAIL) agents could be a very effective therapeutic option for AML patients, as indicated by results obtained in pre-clinical settings.

The spectacular effect of Bcr-Abl tyrosine kinase inhibitors, such as imatinib for the treatment of chronic myelogenous leukemia (CML) patients in the chronic phase of the disease [154], has fed optimism that modulators of signal transduction networks might be very effective also in other types of cancer. However, clinical trials performed with small molecules targeting the PI $3 \mathrm{~K} / \mathrm{Akt} / \mathrm{mTOR}$ pathway have mostly given a disappointing outcome. This fact has led to the suggestion that imatinib success in CML may be the exception and not the rule, because imatinib is one of the few examples of a drug targeting the anomaly which constitutes the underlying pathologic event in the formation of the disorder [155]. Human cancers are known to evolve through a multistage process which can extend over a period of several years. Therefore, they progressively accumulate mutations and epigenetic anomalies in expression of multiple genes [156]. As a consequence, neoplastic disorders are characterized by multiple signaling abnormalities and the deregulated pathways are extremely redundant. Furthermore, the hierarchy of anomalies has not been established in many tumors. Therefore, it could be very difficult to find the right target or combinations of target. 
AML is no exception to this rule. However, the continuous development of molecularly targeted drugs displaying higher selectivity, coupled with additional mechanistic studies and advances in profiling the signaling networks of cancer cells, should make it possible to exploit deregulation of the PI3K/Akt/mTOR cascade to achieve more effective and less toxic therapies for AML.

\section{CONFLICT OF INTEREST}

The authors have no conflict of interests to declare.

\section{ACKNOWLEDGEMENTS}

This work was supported by grants from: Fondazione del Monte di Bologna e Ravenna and Progetti Strategici Università di Bologna EF 2006 to AMM. JAM was supported in part by a grant from the National Institutes of Health (USA) (R01098195).

\section{REFERENCES}

1. Smith M, Barnett M, Bassan R, Gatta G, Tondini C, Kern W. Adult acute myeloid leukaemia. Crit Rev Oncol Hematol 2004;50:197-222.

2. Kantarjian H, O'Brien S, Cortes J, Wierda W, Faderl S, Garcia-Manero G, Issa JP, Estey E, Keating M, Freireich EJ. Therapeutic advances in leukemia and myelodysplastic syndrome over the past 40 years. Cancer 2008;113:1933-52.

3. Ravandi F, Burnett AK, Agura ED, Kantarjian HM. Progress in the treatment of acute myeloid leukemia. Cancer 2007;110:1900-10.

4. Stapnes C, Gjertsen BT, Reikvam H, Bruserud O. Targeted therapy in acute myeloid leukaemia: current status and future directions. Expert Opin Investig Drugs 2009;18:433-55.

5. Nasr R, Lallemand-Breitenbach V, Zhu J, Guillemin MC, de The H. Therapy-induced PML/RARA proteolysis and acute promyelocytic leukemia cure. Clin Cancer Res 2009; 15:63216.

6. Lane SW, Scadden DT, Gilliland DG. The leukemic stem cell niche: current concepts and therapeutic opportunities. Blood 2009; 114:1150-7.

7. Misaghian N, Ligresti G, Steelman LS, Bertrand FE, Basecke J, Libra M, Nicoletti F, Stivala F, Milella M, Tafuri A, Cervello M, Martelli AM, et al. Targeting the leukemic stem cell: the Holy Grail of leukemia therapy. Leukemia 2009;23:2542.

8. McCubrey JA, Abrams SL, Ligresti G, Misaghian N, Wong EW, Steelman LS, Basecke J, Troppmair J, Libra M, Nicoletti F, Molton S, McMahon M, et al. Involvement of p53 and Raf/ $\mathrm{MEK} / \mathrm{ERK}$ pathways in hematopoietic drug resistance. Leukemia 2008;22:2080-90.

9. Steelman LS, Abrams SL, Whelan J, Bertrand FE, Ludwig
DE, Basecke J, Libra M, Stivala F, Milella M, Tafuri A, Lunghi P, Bonati A, et al. Contributions of the Raf/MEK/ ERK, PI3K/PTEN/Akt/mTOR and Jak/STAT pathways to leukemia. Leukemia 2008;22:686-707.

10. Scholl C, Gilliland DG, Frohling S. Deregulation of signaling pathways in acute myeloid leukemia. Semin Oncol 2008;35:336-45.

11. Yuan TL, Cantley LC. PI3K pathway alterations in cancer: variations on a theme. Oncogene 2008;27:5497-510.

12. Martelli AM, Tazzari PL, Evangelisti C, Chiarini F, Blalock WL, Billi AM, Manzoli L, McCubrey JA, Cocco L. Targeting the phosphatidylinositol 3-kinase/Akt/mammalian target of rapamycin module for acute myelogenous leukemia therapy: from bench to bedside. Curr Med Chem 2007;14:2009-23.

13. Horn S, Bergholz U, Jucker M, McCubrey JA, Trumper L, Stocking C, Basecke J. Mutations in the catalytic subunit of class IA PI3K confer leukemogenic potential to hematopoietic cells. Oncogene 2008;27:4096-106.

14. Brazil DP, Yang ZZ, Hemmings BA. Advances in protein kinase B signalling: AKTion on multiple fronts. Trends Biochem Sci 2004;29:233-42.

15. Liu P, Cheng H, Roberts TM, Zhao JJ. Targeting the phosphoinositide 3-kinase pathway in cancer. Nat Rev Drug Discov 2009;8:627-44.

16. Franke TF. PI3K/Akt: getting it right matters. Oncogene 2008;27:6473-88.

17. Jia S, Roberts TM, Zhao JJ. Should individual PI3 kinase isoforms be targeted in cancer? Curr Opin Cell Biol 2009;21:199-208.

18. Fruman DA, Bismuth G. Fine tuning the immune response with PI3K. Immunol Rev 2009;228:253-72.

19. Kok K, Geering B, Vanhaesebroeck B. Regulation of phosphoinositide 3-kinase expression in health and disease. Trends Biochem Sci 2009;34:115-27.

20. Backer JM. The regulation and function of Class III PI3Ks: novel roles for Vps34. Biochem J 2008;410:1-17.

21. Ligresti G, Militello L, Steelman LS, Cavallaro A, Basile F, Nicoletti F, Stivala F, McCubrey JA, Libra M. PIK3CA mutations in human solid tumors: role in sensitivity to various therapeutic approaches. Cell Cycle 2009;8:1352-8.

22. Denley A, Kang S, Karst U, Vogt PK. Oncogenic signaling of class I PI3K isoforms. Oncogene 2008;27:2561-74.

23. Zhao L, Vogt PK. Class I PI $3 \mathrm{~K}$ in oncogenic cellular transformation. Oncogene 2008;27:5486-96.

24. Bae SS, Cho H, Mu J, Birnbaum MJ. Isoform-specific regulation of insulin-dependent glucose uptake by Akt/protein kinase B. J Biol Chem 2003;278:49530-6.

25. Arboleda MJ, Lyons JF, Kabbinavar FF, Bray MR, Snow BE, Ayala R, Danino M, Karlan BY, Slamon DJ. Overexpression of AKT2/protein kinase Bbeta leads to up-regulation of beta1 integrins, increased invasion, and metastasis of human breast and ovarian cancer cells. Cancer Res 2003;63:196-206.

26. Martelli AM, Faenza I, Billi AM, Manzoli L, Evangelisti C, Fala F, Cocco L. Intranuclear 3'-phosphoinositide metabolism and Akt signaling: new mechanisms for tumorigenesis and protection against apoptosis? Cell Signal 2006;18:11017. 
27. Trotman LC, Alimonti A, Scaglioni PP, Koutcher JA, Cordon-Cardo C, Pandolfi PP. Identification of a tumour suppressor network opposing nuclear Akt function. Nature 2006;441:523-7.

28. Wojiski S, Guibal FC, Kindler T, Lee BH, Jesneck JL, Fabian A, Tenen DG, Gilliland DG. PML-RARalpha initiates leukemia by conferring properties of self-renewal to committed promyelocytic progenitors. Leukemia 2009;23:1462-71.

29. Billottet C, Banerjee L, Vanhaesebroeck B, Khwaja A. Inhibition of class I phosphoinositide 3-kinase activity impairs proliferation and triggers apoptosis in acute promyelocytic leukemia without affecting atra-induced differentiation. Cancer Res 2009;69:1027-36.

30. Manning BD, Cantley LC. AKT/PKB signaling: navigating downstream. Cell 2007;129:1261-74.

31. Downward J. PI 3-kinase, Akt and cell survival. Semin Cell Dev Biol 2004; 15:177-82.

32. Carpten JD, Faber AL, Horn C, Donoho GP, Briggs SL, Robbins CM, Hostetter G, Boguslawski S, Moses TY, Savage $\mathrm{S}$, Uhlik M, Lin A, et al. A transforming mutation in the pleckstrin homology domain of AKT1 in cancer. Nature 2007;448:439-44.

33. Memmott RM, Dennis PA. Akt-dependent and -independent mechanisms of mTOR regulation in cancer. Cell Signal 2009;21:656-64.

34. Dunlop EA, Tee AR. Mammalian target of rapamycin complex 1: signalling inputs, substrates and feedback mechanisms. Cell Signal 2009;21:827-35.

35. Rosner M, Hengstschlager M. Cytoplasmic and nuclear distribution of the protein complexes mTORC1 and mTORC2: rapamycin triggers dephosphorylation and delocalization of the mTORC2 components rictor and sin1. Hum Mol Genet 2008;17:2934-48.

36. Tamburini J, Green AS, Chapuis N, Bardet V, Lacombe C, Mayeux P, Bouscary D. Targeting translation in acute myeloid leukemia: A new paradigm for therapy? Cell Cycle 2009;8:3893-9.

37. Mamane Y, Petroulakis E, LeBacquer O, Sonenberg N. mTOR, translation initiation and cancer. Oncogene 2006;25:6416-22.

38. Crazzolara R, Cisterne A, Thien M, Hewson J, Baraz R, Bradstock KF, Bendall LJ. Potentiating effects of RAD001 (Everolimus) on vincristine therapy in childhood acute lymphoblastic leukemia. Blood 2009;113:3297-306.

39. Mavrakis KJ, Zhu H, Silva RL, Mills JR, Teruya-Feldstein J, Lowe SW, Tam W, Pelletier J, Wendel HG. Tumorigenic activity and therapeutic inhibition of Rheb GTPase. Genes Dev 2008;22:2178-88.

40. Wang L, Harris TE, Lawrence JC, Jr. Regulation of prolinerich Akt substrate of $40 \mathrm{kDa}$ (PRAS40) function by mammalian target of rapamycin complex 1 (mTORC1)-mediated phosphorylation. J Biol Chem 2008;283:15619-27.

41. Fonseca BD, Smith EM, Lee VH, MacKintosh C, Proud CG. PRAS40 is a target for mammalian target of rapamycin complex 1 and is required for signaling downstream of this complex. J Biol Chem 2007;282:24514-24.

42. Ma L, Chen Z, Erdjument-Bromage H, Tempst P, Pandolfi PP. Phosphorylation and functional inactivation of TSC 2 by
Erk implications for tuberous sclerosis and cancer pathogenesis. Cell 2005;121:179-93.

43. Vazquez-Martin A, Oliveras-Ferraros C, Lopez-Bonet E, Menendez JA. AMPK: Evidence for an energy-sensing cytokinetic tumor suppressor. Cell Cycle 2009;8:3679-83.

44. Huang J, Manning BD. A complex interplay between Akt, TSC2 and the two mTOR complexes. Biochem Soc Trans 2009;37:217-22.

45. Sarbassov DD, Guertin DA, Ali SM, Sabatini DM. Phosphorylation and regulation of Akt/PKB by the rictor-mTOR complex. Science 2005;307:1098-101.

46. Jacinto E, Loewith R, Schmidt A, Lin S, Ruegg MA, Hall A, Hall MN. Mammalian TOR complex 2 controls the actin cytoskeleton and is rapamycin insensitive. Nat Cell Biol 2004;6:1122-8.

47. Garcia-Martinez JM, Alessi DR. mTOR complex 2 (mTORC2) controls hydrophobic motif phosphorylation and activation of serum- and glucocorticoid-induced protein kinase 1 (SGK1). Biochem J 2008;416:375-85.

48. Guertin DA, Stevens DM, Saitoh M, Kinkel S, Crosby K, Sheen JH, Mullholland DJ, Magnuson MA, Wu H, Sabatini DM. mTOR complex 2 is required for the development of prostate cancer induced by Pten loss in mice. Cancer Cell 2009;15:148-59.

49. Shah OJ, Wang Z, Hunter T. Inappropriate activation of the TSC/Rheb/mTOR/S6K cassette induces IRS1/2 depletion, insulin resistance, and cell survival deficiencies. Curr Biol 2004;14:1650-6.

50. Bhaskar PT, Hay N. The two TORCs and Akt. Dev Cell 2007; 12:487-502.

51. Xu X, Sarikas A, Dias-Santagata DC, Dolios G, Lafontant PJ, Tsai SC, Zhu W, Nakajima H, Nakajima HO, Field LJ, Wang R, Pan ZQ. The CUL7 E3 ubiquitin ligase targets insulin receptor substrate 1 for ubiquitin-dependent degradation. Mol Cell 2008;30:403-14.

52. Shi Y, Yan H, Frost P, Gera J, Lichtenstein A. Mammalian target of rapamycin inhibitors activate the AKT kinase in multiple myeloma cells by up-regulating the insulin-like growth factor receptor/insulin receptor substrate-1/phosphatidylinositol 3-kinase cascade. Mol Cancer Ther 2005;4:1533-40.

53. Breuleux M, Klopfenstein M, Stephan C, Doughty CA, Barys L, Maira SM, Kwiatkowski D, Lane HA. Increased AKT S473 phosphorylation after mTORC1 inhibition is rictor dependent and does not predict tumor cell response to PI3K/ mTOR inhibition. Mol Cancer Ther 2009;8:742-53.

54. Sriburi R, Jackowski S, Mori K, Brewer JW. XBP1: a link between the unfolded protein response, lipid biosynthesis, and biogenesis of the endoplasmic reticulum. J Cell Biol 2004;167:35-41.

55. Tamburini J, Chapuis N, Bardet V, Park S, Sujobert P, Willems L, Ifrah N, Dreyfus F, Mayeux P, Lacombe C, Bouscary D. Mammalian target of rapamycin (mTOR) inhibition activates phosphatidylinositol 3-kinase/Akt by up-regulating insulin-like growth factor-1 receptor signaling in acute myeloid leukemia: rationale for therapeutic inhibition of both pathways. Blood 2008;111:379-82.

56. Dibble CC, Asara JM, Manning BD. Characterization of Rictor phosphorylation sites reveals direct regulation of 
mTOR complex 2 by S6K1. Mol Cell Biol 2009;29:5657-70.

57. O'Reilly KE, Rojo F, She QB, Solit D, Mills GB, Smith D, Lane H, Hofmann F, Hicklin DJ, Ludwig DL, Baselga J, Rosen N. mTOR inhibition induces upstream receptor tyrosine kinase signaling and activates Akt. Cancer Res 2006;66:1500-8.

58. Keniry M, Parsons R. The role of PTEN signaling perturbations in cancer and in targeted therapy. Oncogene 2008;27:5477-85.

59. Stiles BL. Phosphatase and tensin homologue deleted on chromosome 10: extending its PTENtacles. Int J Biochem Cell Biol 2009;41:757-61.

60. Gutierrez A, Sanda T, Grebliunaite R, Carracedo A, Salmena L, Ahn Y, Dahlberg S, Neuberg D, Moreau LA, Winter SS, Larson R, Zhang J, et al. High frequency of PTEN, PI3K and AKT abnormalities in $\mathrm{T}$ cell acute lymphoblastic leukemia. Blood 2009; 114:647-50.

61. Kalesnikoff J, Sly LM, Hughes MR, Buchse T, Rauh MJ, Cao LP, Lam V, Mui A, Huber M, Krystal G. The role of SHIP in cytokine-induced signaling. Rev Physiol Biochem Pharmacol 2003;149:87-103.

62. Ong CJ, Ming-Lum A, Nodwell M, Ghanipour A, Yang L, Williams DE, Kim J, Demirjian L, Qasimi P, Ruschmann J, Cao LP, Ma K, et al. Small-molecule agonists of SHIP1 inhibit the phosphoinositide 3-kinase pathway in hematopoietic cells. Blood 2007;110:1942-9.

63. Hazen AL, Smith MJ, Desponts C, Winter O, Moser K, Kerr WG. SHIP is required for a functional hematopoietic stem cell niche. Blood 2009;113:2924-33.

64. Eichhorn PJ, Creyghton MP, Bernards R. Protein phosphatase $2 \mathrm{~A}$ regulatory subunits and cancer. Biochim Biophys Acta 2009;1795:1-15.

65. Brognard J, Newton AC. PHLiPPing the switch on Akt and protein kinase $\mathrm{C}$ signaling. Trends Endocrinol Metab 2008;19:223-30.

66. Xu Q, Simpson SE, Scialla TJ, Bagg A, Carroll M. Survival of acute myeloid leukemia cells requires PI3 kinase activation. Blood 2003;102:972-80.

67. Min YH, Eom JI, Cheong JW, Maeng HO, Kim JY, Jeung HK, Lee ST, Lee MH, Hahn JS, Ko YW. Constitutive phosphorylation of Akt/PKB protein in acute myeloid leukemia: its significance as a prognostic variable. Leukemia 2003;17:995-7.

68. Brandts CH, Sargin B, Rode M, Biermann C, Lindtner B, Schwable J, Buerger H, Muller-Tidow C, Choudhary C, McMahon M, Berdel WE, Serve H. Constitutive activation of Akt by Flt3 internal tandem duplications is necessary for increased survival, proliferation, and myeloid transformation. Cancer Res 2005;65:9643-50.

69. Grandage VL, Gale RE, Linch DC, Khwaja A. PI3-kinase/ Akt is constitutively active in primary acute myeloid leukaemia cells and regulates survival and chemoresistance via NF-kappaB, Mapkinase and p53 pathways. Leukemia 2005;19:586-94.

70. Gallay N, Dos Santos C, Cuzin L, Bousquet M, Simmonet Gouy V, Chaussade C, Attal M, Payrastre B, Demur C, Recher C. The level of AKT phosphorylation on threonine 308 but not on serine 473 is associated with high-risk cytogenetics and predicts poor overall survival in acute myeloid leukaemia. Leukemia 2009;23:1029-38.

71. Muranyi AL, Dedhar S, Hogge DE. Combined inhibition of integrin linked kinase and FMS-like tyrosine kinase 3 is cytotoxic to acute myeloid leukemia progenitor cells. Exp Hematol 2009;37:450-60.

72. Min YH, Cheong JW, Kim JY, Eom JI, Lee ST, Hahn JS, Ko YW, Lee MH. Cytoplasmic mislocalization of p27Kip1 protein is associated with constitutive phosphorylation of Akt or protein kinase $\mathrm{B}$ and poor prognosis in acute myelogenous leukemia. Cancer Res 2004;64:5225-31.

73. Kornblau SM, Womble M, Qiu YH, Jackson CE, Chen W, Konopleva M, Estey EH, Andreeff M. Simultaneous activation of multiple signal transduction pathways confers poor prognosis in acute myelogenous leukemia. Blood 2006;108:2358-65.

74. Kornblau SM, Tibes R, Qiu YH, Chen W, Kantarjian HM, Andreeff M, Coombes KR, Mills GB. Functional proteomic profiling of AML predicts response and survival. Blood 2009;113:154-64.

75. Tazzari PL, Cappellini A, Ricci F, Evangelisti C, Papa V, Grafone T, Martinelli G, Conte R, Cocco L, McCubrey JA, Martelli AM. Multidrug resistance-associated protein 1 expression is under the control of the phosphoinositide 3 kinase/Akt signal transduction network in human acute myelogenous leukemia blasts. Leukemia 2007;21:427-38.

76. Schaich M, Soucek S, Thiede C, Ehninger G, Illmer T. MDR1 and MRP1 gene expression are independent predictors for treatment outcome in adult acute myeloid leukaemia. Br J Haematol 2005;128:324-32.

77. Tamburini J, Elie C, Bardet V, Chapuis N, Park S, Broet P, Cornillet-Lefebvre P, Lioure B, Ugo V, Blanchet O, Ifrah N, Witz F, et al. Constitutive phosphoinositide 3-kinase/Akt activation represents a favorable prognostic factor in de novo acute myelogenous leukemia patients. Blood 2007;110:10258.

78. Faderl S, Pal A, Bornmann W, Albitar M, Maxwell D, Van Q, Peng Z, Harris D, Liu Z, Hazan-Halevy I, Kantarjian HM, Estrov Z. Kit inhibitor APcK110 induces apoptosis and inhibits proliferation of acute myeloid leukemia cells. Cancer Res 2009;69:3910-7.

79. Birkenkamp KU, Geugien M, Schepers H, Westra J, Lemmink HH, Vellenga E. Constitutive NF-kappaB DNA-binding activity in AML is frequently mediated by a Ras/PI3-K/ PKB-dependent pathway. Leukemia 2004;18:103-12.

80. Sujobert P, Bardet V, Cornillet-Lefebvre P, Hayflick JS, Prie $\mathrm{N}$, Verdier F, Vanhaesebroeck B, Muller O, Pesce F, Ifrah $\mathrm{N}$, Hunault-Berger M, Berthou C, et al. Essential role for the p110delta isoform in phosphoinositide 3-kinase activation and cell proliferation in acute myeloid leukemia. Blood 2005;106:1063-6.

81. Billottet C, Grandage VL, Gale RE, Quattropani A, Rommel C, Vanhaesebroeck B, Khwaja A. A selective inhibitor of the p110delta isoform of PI 3-kinase inhibits AML cell proliferation and survival and increases the cytotoxic effects of VP16. Oncogene 2006;25:6648-59.

82. Doepfner KT, Spertini O, Arcaro A. Autocrine insulin-like growth factor-I signaling promotes growth and survival of human acute myeloid leukemia cells via the phosphoinositide 3-kinase/Akt pathway. Leukemia 2007;21:1921-30. 
83. Tazzari PL, Tabellini G, Bortul R, Papa V, Evangelisti C, Grafone T, Martinelli G, McCubrey JA, Martelli AM. The insulin-like growth factor-I receptor kinase inhibitor NVPAEW541 induces apoptosis in acute myeloid leukemia cells exhibiting autocrine insulin-like growth factor-I secretion. Leukemia 2007;21:886-96.

84. Wahner Hendrickson AE, Haluska P, Schneider PA, Loegering DA, Peterson KL, Attar R, Smith BD, Erlichman C, Gottardis M, Karp JE, Carboni JM, Kaufmann SH. Expression of insulin receptor isoform A and insulin-like growth factor-1 receptor in human acute myelogenous leukemia: effect of the dual-receptor inhibitor BMS-536924 in vitro. Cancer Res 2009;69:7635-43.

85. Imai N, Miwa H, Shikami M, Suganuma K, Gotoh M, Hiramatsu A, Wakabayashi M, Watarai M, Hanamura I, Imamura A, Mihara H, Shitara K, et al. Growth inhibition of AML cells with specific chromosome abnormalities by monoclonal antibodies to receptors for vascular endothelial growth factor. Leuk Res 2009;33:1650-7.

86. Bohm A, Aichberger KJ, Mayerhofer M, Herrmann H, Florian S, Krauth MT, Derdak S, Samorapoompichit P, Sonneck $\mathrm{K}$, Vales A, Gleixner KV, Pickl WF, et al. Targeting of mTOR is associated with decreased growth and decreased VEGF expression in acute myeloid leukaemia cells. Eur J Clin Invest 2009;39:395-405.

87. Pearn L, Fisher J, Burnett AK, Darley RL. The role of PKC and PDK1 in monocyte lineage specification by Ras. Blood 2007;109:4461-9.

88. Fierro FA, Brenner S, Oelschlaegel U, Jacobi A, Knoth H, Ehninger G, Illmer T, Bornhauser M. Combining SDF-1/ CXCR4 antagonism and chemotherapy in relapsed acute myeloid leukemia. Leukemia 2009;23:393-6.

89. Fiegl M, Samudio I, Clise-Dwyer K, Burks JK, Mnjoyan $\mathrm{Z}$, Andreeff M. CXCR4 expression and biologic activity in acute myeloid leukemia are dependent on oxygen partial pressure. Blood 2009;113:1504-12.

90. Ayala F, Dewar R, Kieran M, Kalluri R. Contribution of bone microenvironment to leukemogenesis and leukemia progression. Leukemia 2009;23:2233-41.

91. Zeng Z, Shi YX, Samudio IJ, Wang RY, Ling X, Frolova O, Levis M, Rubin JB, Negrin RR, Estey EH, Konoplev S, Andreeff $\mathrm{M}$, et al. Targeting the leukemia microenvironment by CXCR4 inhibition overcomes resistance to kinase inhibitors and chemotherapy in AML. Blood 2009;113:6215-24.

92. Matsunaga T, Takemoto N, Sato T, Takimoto R, Tanaka I, Fujimi A, Akiyama T, Kuroda H, Kawano Y, Kobune M, Kato J, Hirayama Y, et al. Interaction between leukemic-cell VLA-4 and stromal fibronectin is a decisive factor for minimal residual disease of acute myelogenous leukemia. Nat Med 2003;9:1158-65.

93. Matsunaga T, Fukai F, Miura S, Nakane Y, Owaki T, Kodama H, Tanaka M, Nagaya T, Takimoto R, Takayama T, Niitsu Y. Combination therapy of an anticancer drug with the FNIII14 peptide of fibronectin effectively overcomes cell adhesionmediated drug resistance of acute myelogenous leukemia. Leukemia 2008;22:353-60.

94. Tabe Y, Jin L, Tsutsumi-Ishii Y, Xu Y, McQueen T, Priebe W, Mills GB, Ohsaka A, Nagaoka I, Andreeff M, Konopleva M. Activation of integrin-linked kinase is a critical prosurvival pathway induced in leukemic cells by bone marrow-derived stromal cells. Cancer Res 2007;67:684-94.

95. McDonald PC, Oloumi A, Mills J, Dobreva I, Maidan M, Gray V, Wederell ED, Bally MB, Foster LJ, Dedhar S. Rictor and integrin-linked kinase interact and regulate Akt phosphorylation and cancer cell survival. Cancer Res 2008;68:1618-24.

96. Bousquet M, Recher C, Queleen C, Demur C, Payrastre B, Brousset P. Assessment of somatic mutations in phosphatidylinositol 3-kinase gene in human lymphoma and acute leukaemia. Br J Haematol 2005;131:411-3.

97. Tibes R, Kornblau SM, Qiu Y, Mousses SM, Robbins C, Moses T, Carpten JD. PI3K/AKT pathway activation in acute myeloid leukaemias is not associated with AKT1 pleckstrin homology domain mutation. Br J Haematol 2008;140:344-7.

98. Vazquez F, Ramaswamy S, Nakamura N, Sellers WR. Phosphorylation of the PTEN tail regulates protein stability and function. Mol Cell Biol 2000;20:5010-8.

99. Cheong JW, Eom JI, Maeng HY, Lee ST, Hahn JS, Ko YW, Min YH. Phosphatase and tensin homologue phosphorylation in the C-terminal regulatory domain is frequently observed in acute myeloid leukaemia and associated with poor clinical outcome. Br J Haematol 2003;122:454-6.

100. Yilmaz OH, Valdez R, Theisen BK, Guo W, Ferguson DO, $\mathrm{Wu} \mathrm{H}$, Morrison SJ. Pten dependence distinguishes haematopoietic stem cells from leukaemia-initiating cells. Nature 2006;441:475-82.

101.Zhang J, Grindley JC, Yin T, Jayasinghe S, He XC, Ross JT, Haug JS, Rupp D, Porter-Westpfahl KS, Wiedemann LM, $\mathrm{Wu} \mathrm{H}, \mathrm{Li}$ L. PTEN maintains haematopoietic stem cells and acts in lineage choice and leukaemia prevention. Nature 2006;441:518-22.

102. Chow S, Minden MD, Hedley DW. Constitutive phosphorylation of the S6 ribosomal protein via mTOR and ERK signaling in the peripheral blasts of acute leukemia patients. Exp Hematol 2006;34:1183-91.

103.Dos Santos C, Demur C, Bardet V, Prade-Houdellier N, Payrastre B, Recher C. A critical role for Lyn in acute myeloid leukemia. Blood 2008;111:2269-79.

104.Xu Z, Wang M, Wang L, Wang Y, Zhao X, Rao Q, Wang J. Aberrant expression of TSC 2 gene in the newly diagnosed acute leukemia. Leuk Res 2009;33:891-7.

105.Xu Q, Thompson JE, Carroll M. mTOR regulates cell survival after etoposide treatment in primary AML cells. Blood 2005;106:4261-8.

106. Vanhaesebroeck B, Leevers SJ, Ahmadi K, Timms J, Katso R, Driscoll PC, Woscholski R, Parker PJ, Waterfield MD. Synthesis and function of 3-phosphorylated inositol lipids. Annu Rev Biochem 2001;70:535-602.

107.Bozulic L, Surucu B, Hynx D, Hemmings BA. PKBalpha/ Akt1 acts downstream of DNA-PK in the DNA double-strand break response and promotes survival. Mol Cell 2008;30:20313.

108.Neri LM, Borgatti P, Tazzari PL, Bortul R, Cappellini A, Tabellini G, Bellacosa A, Capitani S, Martelli AM. The phosphoinositide 3-kinase/AKT1 pathway involvement in drug and all-trans-retinoic acid resistance of leukemia cells. Mol Cancer Res 2003;1:234-46.

109.Zhao S, Konopleva M, Cabreira-Hansen M, Xie Z, Hu W, 
Milella M, Estrov Z, Mills GB, Andreeff M. Inhibition of phosphatidylinositol 3-kinase dephosphorylates BAD and promotes apoptosis in myeloid leukemias. Leukemia 2004; $18: 267-75$

110.Garcia-Echeverria C, Sellers WR. Drug discovery approaches targeting the PI3K/Akt pathway in cancer. Oncogene 2008;27:5511-26.

111. Ihle NT, Powis G. Take your PIK: phosphatidylinositol 3-kinase inhibitors race through the clinic and toward cancer therapy. Mol Cancer Ther 2009;8:1-9.

112. Foukas LC, Claret M, Pearce W, Okkenhaug K, Meek S, Peskett E, Sancho S, Smith AJ, Withers DJ, Vanhaesebroeck B. Critical role for the p110alpha phosphoinositide-3-OH kinase in growth and metabolic regulation. Nature 2006;441:36670.

113 Knight ZA, Gonzalez B, Feldman ME, Zunder ER, Goldenberg DD, Williams O, Loewith R, Stokoe D, Balla A, Toth B, Balla T, Weiss WA, et al. A pharmacological map of the PI3-K family defines a role for p110alpha in insulin signaling. Cell 2006;125:733-47.

114.Fu L, Kim YA, Wang X, Wu X, Yue P, Lonial S, Khuri FR, Sun SY. Perifosine Inhibits Mammalian Target of Rapamycin Signaling through Facilitating Degradation of Major Components in the mTOR Axis and Induces Autophagy. Cancer Res 2009;69:8967-76.

115.van Blitterswijk WJ, Verheij M. Anticancer alkylphospholipids: mechanisms of action, cellular sensitivity and resistance, and clinical prospects. Curr Pharm Des 2008;14:2061-74.

116. Papa V, Tazzari PL, Chiarini F, Cappellini A, Ricci F, Billi AM, Evangelisti C, Ottaviani E, Martinelli G, Testoni N, McCubrey JA, Martelli AM. Proapoptotic activity and chemosensitizing effect of the novel Akt inhibitor perifosine in acute myelogenous leukemia cells. Leukemia 2008;22:14760.

117.Rahmani M, Reese E, Dai Y, Bauer C, Payne SG, Dent P, Spiegel S, Grant S. Coadministration of histone deacetylase inhibitors and perifosine synergistically induces apoptosis in human leukemia cells through Akt and ERK1/2 inactivation and the generation of ceramide and reactive oxygen species. Cancer Res 2005;65:2422-32.

118. Tazzari PL, Tabellini G, Ricci F, Papa V, Bortul R, Chiarini F, Evangelisti C, Martinelli G, Bontadini A, Cocco L, McCubrey JA, Martelli AM. Synergistic proapoptotic activity of recombinant TRAIL plus the Akt inhibitor Perifosine in acute myelogenous leukemia cells. Cancer Res 2008;68:9394-403.

119. Chiarini F, Del Sole M, Mongiorgi S, Gaboardi GC, Cappellini A, Mantovani I, Follo MY, McCubrey JA, Martelli AM. The novel Akt inhibitor, perifosine, induces caspase-dependent apoptosis and downregulates P-glycoprotein expression in multidrug-resistant human T-acute leukemia cells by a JNK-dependent mechanism. Leukemia 2008;22:1106-16.

120.Rahmani M, Anderson A, Habibi JR, Crabtree TR, Mayo M, Harada H, Ferreira-Gonzalez A, Dent P, Grant S. The BH3only protein Bim plays a critical role in leukemia cell death triggered by concomitant inhibition of the PI3K/Akt and MEK/ERK1/2 pathways. Blood 2009;114:4507-16.

121.Barnett SF, Defeo-Jones D, Fu S, Hancock PJ, Haskell KM, Jones RE, Kahana JA, Kral AM, Leander K, Lee LL, Malinowski J, McAvoy EM, et al. Identification and char- acterization of pleckstrin-homology-domain-dependent and isoenzyme-specific Akt inhibitors. Biochem J 2005;385:399408.

122.Fasolo A, Sessa C. mTOR inhibitors in the treatment of cancer. Expert Opin Investig Drugs 2008;17:1717-34.

123.Hudes G, Carducci M, Tomczak P, Dutcher J, Figlin R, Kapoor A, Staroslawska E, Sosman J, McDermott D, Bodrogi I, Kovacevic Z, Lesovoy V, et al. Temsirolimus, interferon alfa, or both for advanced renal-cell carcinoma. N Engl J Med 2007;356:2271-81.

124.Meric-Bernstam F, Gonzalez-Angulo AM. Targeting the mTOR signaling network for cancer therapy. J Clin Oncol 2009;27:2278-87.

125.Abraham RT, Gibbons JJ. The mammalian target of rapamycin signaling pathway: twists and turns in the road to cancer therapy. Clin Cancer Res 2007;13:3109-14.

126.Leone M, Crowell KJ, Chen J, Jung D, Chiang GG, Sareth S, Abraham RT, Pellecchia M. The FRB domain of mTOR: NMR solution structure and inhibitor design. Biochemistry 2006;45:10294-302.

127.Foster DA, Toschi A. Targeting mTOR with rapamycin: one dose does not fit all. Cell Cycle 2009;8:1026-9.

128.Zeng Z, Sarbassov dos D, Samudio IJ, Yee KW, Munsell MF, Ellen Jackson C, Giles FJ, Sabatini DM, Andreeff M, Konopleva M. Rapamycin derivatives reduce mTORC2 signaling and inhibit AKT activation in AML. Blood 2007;109:350912.

129. Recher C, Beyne-Rauzy O, Demur C, Chicanne G, Dos Santos C, Mas VM, Benzaquen D, Laurent G, Huguet F, Payrastre B. Antileukemic activity of rapamycin in acute myeloid leukemia. Blood 2005;105:2527-34.

130.Nishioka C, Ikezoe T, Yang J, Gery S, Koeffler HP, Yokoyama A. Inhibition of mammalian target of rapamycin signaling potentiates the effects of all-trans retinoic acid to induce growth arrest and differentiation of human acute myelogenous leukemia cells. Int J Cancer 2009;125:1710-20.

131.Nishioka C, Ikezoe T, Yang J, Koeffler HP, Yokoyama A. Blockade of mTOR signaling potentiates the ability of histone deacetylase inhibitor to induce growth arrest and differentiation of acute myelogenous leukemia cells. Leukemia 2008;22:2159-68.

132. Yee KW, Zeng Z, Konopleva M, Verstovsek S, Ravandi F, Ferrajoli A, Thomas D, Wierda W, Apostolidou E, Albitar M, O'Brien S, Andreeff M, et al. Phase I/II study of the mammalian target of rapamycin inhibitor everolimus (RAD001) in patients with relapsed or refractory hematologic malignancies. Clin Cancer Res 2006;12:5165-73.

133.Rizzieri DA, Feldman E, Dipersio JF, Gabrail N, Stock W, Strair R, Rivera VM, Albitar M, Bedrosian CL, Giles FJ. A phase 2 clinical trial of deforolimus (AP23573, MK-8669), a novel mammalian target of rapamycin inhibitor, in patients with relapsed or refractory hematologic malignancies. Clin Cancer Res 2008; 14:2756-62.

134.Perl AE, Kasner MT, Tsai DE, Vogl DT, Loren AW, Schuster SJ, Porter DL, Stadtmauer EA, Goldstein SC, Frey NV, Nasta $\mathrm{SD}$, Hexner EO, et al. A phase I study of the mammalian target of rapamycin inhibitor sirolimus and MEC chemotherapy in relapsed and refractory acute myelogenous leukemia. 
Clin Cancer Res 2009;15:6732-9.

135. Teachey DT, Grupp SA, Brown VI. Mammalian target of rapamycin inhibitors and their potential role in therapy in leukaemia and other haematological malignancies. Br J Haematol 2009;145:569-80.

136.Karp JE, Flatten K, Feldman EJ, Greer JM, Loegering DA, Ricklis RM, Morris LE, Ritchie E, Smith BD, Ironside V, Talbott T, Roboz G, et al. Active oral regimen for elderly adults with newly diagnosed acute myelogenous leukemia: a preclinical and phase 1 trial of the farnesyltransferase inhibitor tipifarnib (R115777, Zarnestra) combined with etoposide. Blood 2009;113:4841-52.

137.Feldman ME, Apsel B, Uotila A, Loewith R, Knight ZA, Ruggero D, Shokat KM. Active-site inhibitors of mTOR target rapamycin-resistant outputs of $\mathrm{mTORC} 1$ and $\mathrm{mTORC} 2$. PLoS Biol 2009; 7:e38.

138. Thoreen CC, Kang SA, Chang JW, Liu Q, Zhang J, Gao Y, Reichling LJ, Sim T, Sabatini DM, Gray NS. An ATP-competitive mammalian target of rapamycin inhibitor reveals rapamycin-resistant functions of mTORC1. J Biol Chem 2009;284:8023-32.

139. Garcia-Martinez JM, Moran J, Clarke RG, Gray A, Cosulich SC, Chresta CM, Alessi DR. Ku-0063794 is a specific inhibitor of the mammalian target of rapamycin (mTOR). Biochem J 2009;421:29-42.

140. Yu K, Toral-Barza L, Shi C, Zhang WG, Lucas J, Shor B, Kim J, Verheijen J, Curran K, Malwitz DJ, Cole DC, Ellingboe J, et al. Biochemical, cellular, and in vivo activity of novel ATPcompetitive and selective inhibitors of the mammalian target of rapamycin. Cancer Res 2009;69:6232-40.

141. Nowak P, Cole DC, Brooijmans N, Bursavich MG, Curran KJ, Ellingboe JW, Gibbons JJ, Hollander I, Hu Y, Kaplan J, Malwitz DJ, Toral-Barza L, et al. Discovery of potent and selective inhibitors of the mammalian target of rapamycin (mTOR) kinase. J Med Chem 2009;52:7081-9.

142. Tamburini J, Green AS, Bardet V, Chapuis N, Park S, Willems L, Uzunov M, Ifrah N, Dreyfus F, Lacombe C, Mayeux $\mathrm{P}$, Bouscary D. Protein synthesis is resistant to rapamycin and constitutes a promising therapeutic target in acute myeloid leukemia. Blood 2009; 114:1618-27.

143.Fan QW, Knight ZA, Goldenberg DD, Yu W, Mostov KE, Stokoe D, Shokat KM, Weiss WA. A dual PI3 kinase/mTOR inhibitor reveals emergent efficacy in glioma. Cancer Cell 2006;9:341-9.

144. Raynaud FI, Eccles S, Clarke PA, Hayes A, Nutley B, Alix S, Henley A, Di-Stefano F, Ahmad Z, Guillard S, Bjerke LM, Kelland L, et al. Pharmacologic characterization of a potent inhibitor of class I phosphatidylinositide 3-kinases. Cancer Res 2007;67:5840-50.

145. Steelman LS, McCubrey JA. Intriguing novel abilities of Nutlin-3A: induction of cellular quiescence as opposed to cellular senescence--implications for chemotherapy. Cell Cycle 2009;8:3634-5.

146.Korotchkina LG, Demidenko ZN, Gudkov AV, Blagosklonny MV. Cellular quiescence caused by the Mdm2 inhibitor nutlin-3A. Cell Cycle 2009;8:3777-81.

147.Kojima K, Shimanuki M, Shikami M, Samudio IJ, Ruvolo V, Corn P, Hanaoka N, Konopleva M, Andreeff M, Nakakuma
H. The dual PI3 kinase/mTOR inhibitor PI-103 prevents p53 induction by Mdm2 inhibition but enhances p53-mediated mitochondrial apoptosis in p53 wild-type AML. Leukemia 2008;22:1728-36.

148.Park S, Chapuis N, Bardet V, Tamburini J, Gallay N, Willems L, Knight ZA, Shokat KM, Azar N, Viguie F, Ifrah N, Dreyfus F, et al. PI-103, a dual inhibitor of Class IA phosphatidylinositide 3-kinase and mTOR, has antileukemic activity in AML. Leukemia 2008;22:1698-706.

149. Shor B, Gibbons JJ, Abraham RT, Yu K. Targeting mTOR globally in cancer: Thinking beyond rapamycin. Cell Cycle 2009;8:3831-7.

150.Yap TA, Garrett MD, Walton MI, Raynaud F, de Bono JS, Workman P. Targeting the PI3K-AKT-mTOR pathway: progress, pitfalls, and promises. Curr Opin Pharmacol 2008;8:393412.

151.Engelman JA. Targeting PI3K signalling in cancer: opportunities, challenges and limitations. Nat Rev Cancer 2009;9:55062.

152.Tazzari PL, Cappellini A, Grafone T, Mantovani I, Ricci F, Billi AM, Ottaviani E, Conte R, Martinelli G, Martelli AM. Detection of serine 473 phosphorylated Akt in acute myeloid leukaemia blasts by flow cytometry. Br J Haematol 2004;126:675-81.

153. Bardet V, Tamburini J, Ifrah N, Dreyfus F, Mayeux P, Bouscary D, Lacombe C. Single cell analysis of phosphoinositide 3-kinase/Akt and ERK activation in acute myeloid leukemia by flow cytometry. Haematologica 2006;91:757-64.

154.Gora-Tybor J, Robak T. Targeted drugs in chronic myeloid leukemia. Curr Med Chem 2008;15:3036-51.

155. Hambley TW, Hait WN. Is anticancer drug development heading in the right direction? Cancer Res 2009;69:1259-62.

156. Weinstein IB, Joe A. Oncogene addiction. Cancer Res 2008;68:3077-80; discussion 80 . 